concept that individual diseases exhibit unique characteristics. Taking these characteristics into account should enable a more accurate assessment of disease severity. Numerous examples exist of disease-specific scores that outperform generic scores, ${ }^{13}{ }^{14}$ including the PSI in the context of patients hospitalised with CAP. ${ }^{15}$ The study by Barlow et al extends this view to CURB65 in relation to SEWS and SIRS. However, the patient cohort in this study differs from other CAP cohorts in two substantial ways: (1) only $52 \%$ of the patients had chest radiographic confirmation of pneumonia and (2) the overall mortality of the cohort was high (19\%) compared with other CAP studies such as the study by Man et $a l^{3}$ in which the mortality rate was $8.6 \%$ (mean age of the cohorts was 74 years and 72 years, respectively). Confirmation of these findings in a separate cohort is therefore desirable.

Generic scores such as SIRS and SEWS have their roots in critical care and anaesthesia. These areas of medicine manage patients with diverse surgical and medical illnesses. The use of generic scores to triage and assess a wide casemix of patients in a standardised manner is helpful. However, when managing an individual patient with a specific disease, they should be used alongside diseasespecific severity scores that are likely to be more accurate, as is the case for CAP.

Where to from here? In the assessment of CAP we now have two validated tools that are reasonably good at stratifying patients according to mortality-the PSI and the CURB65 score. Each of these tools has advantages and disadvantages. ${ }^{16}{ }^{17}$ Centres should therefore adopt the tool that best suits the local healthcare setting. With regard to research, further validation of these tools in different patient cohorts, though desirable, should not detract from the pressing need to determine whether the use of severity assessment tools in the management of CAP ultimately leads to improved clinical outcomes. ${ }^{18}$ Such intervention studies are needed if optimal management strategies for patients in different prognostic groups are to be defined.

Thorax 2007;62:287-288.

doi: $10.1136 /$ thx. 2006.073700

Correspondence to: Dr Wei Shen Lim, Nottingham University Hospitals, City Hospital Campus, Hucknall Road, Nottingham NG5 1PB, UK; weishen.lim@nuh.nhs.uk

Competing interests: None.

\section{REFERENCES}

1 Fine MJ, Auble TE, Yealy DM, et al. A prediction rule to identify low-risk patients with communityacquired pneumonia [see comments]. N Engl J Med 1997:336:243-50.

2 Lim WS, van der Eerden MM, Laing R, et al. Defining community acquired pneumonia severity on presentation to hospital: an international derivation and validation study. Thorax 2003;58:377-82.

3 Man SY, Lee N, Ip M, et al. Prospective comparison of three predictive rules for assessing severity of community-acquired pneumonia in Hong Kong. Thorax 2007; 62:348-53.

4 Capelastegui A, Espana PP, Quintana JM, et al. Validation of a predictive rule for the management of community-acquired pneumonia. Eur Respir J 2006;27:151-7.

5 Myint PK, Kamath AV, Vowler SL, et al. Severity assessment criteria recommended by the British Thoracic Society (BTS) for community-acquired pneumonia (CAP) and older patients. Should SOAR (systolic blood pressure, oxygenation, age and respiratory rate) criteria be used in older people? A compilation study of two prospective cohorts. Age Ageing 2006;35:286-91.
6 Aujesky D, Auble TE, Yealy DM, et al. Prospective comparison of three validated prediction rules for prognosis in community-acquired pneumonia. Am J Med 2005: 118:384-92.

7 Barlow GD, Nathwani D, Davey PG. The CURB65 pneumonia severity score outperforms generic sepsis and early warning scores in predicting mortality in community-acquired pneumonia. Thorax 2007:62:000-0.

8 Spindler C, Ortqvist A. Prognostic score systems and community-acquired bacteraemic pneumococcal pneumonia. Eur Respir $J$ 2006;28:816-23.

9 Buising KL, Thursky KA, Black JF, et al. A prospective comparison of severity scores for identifying patients with severe community acquired pneumonia: reconsidering what is meant by severe pneumonia. Thorax 2006:61:419-24.

10 Baver TT, Ewig S, Marre R, et al. CRB-65 predicts death from community-acquired pneumonia. $J$ Intern Med 2006;260:93-101.

11 Espana PP, Capelastegui A, Gorordo I, et al. Development and validation of a clinical prediction rule for severe community-acquired pneumonia. Am J Respir Crit Care Med 2006;174:1249-56.

12 Ewig S, de Roux A, Bauer T, et al. Validation of predictive rules and indices of severity for community acquired pneumonia. Thorax 2004;59:421-7.

13 lezzoni LI, Ash AS, Coffman GA, et al. Predicting in-hospital mortality. A comparison of severity measurement approaches. Med Care 1992;30:347-59

14 Daley J, Jencks S, Draper D, et al. Predicting hospital-associated mortality for Medicare patients. A method for patients with stroke, pneumonia, acute myocardial infarction, and congestive heart failure. JAMA 1988;260:3617-24.

15 Fine MJ, Hanusa BH, Lave JR, et al. Comparison of a disease-specific and a generic severity of illness measure for patients with community-acquired pneumonia [see comments]. J Gen Intern Med 1995; 10:359-68.

16 Ewig S, Torres A, Woodhead M. Assessment of pneumonia severity: a European perspective. Eur Respir J 2006;27:6-8.

17 Niederman MS, Feldman C, Richards GA Combining information from prognostic scoring tools for CAP: an American view on how to get the best of all worlds. Eur Respir J 2006;27:9-11.

18 Marrie TJ, Lau CY, Wheeler SL, et al. A controlled trial of a critical pathway for treatment of community-acquired pneumonia. CAPITAL Study Investigators. Community-Acquired Pneumonia Intervention Trial Assessing Levofloxacin. JAMA 2000;283:749-55.

\title{
Pulmonary exacerbations in cystic fibrosis and bronchiectasis
}

\section{J S Elborn, S C Bell}

\section{A series of papers reviewing pulmonary exacerbations in CF and bronchiectasis}

$\mathrm{n}$ the current (see page 360) and forthcoming issues of Thorax we are publishing a series examining current practice and evidence of the epidemiology and pathogenesis, prevention and treatment of pulmonary exacerbations in patients with cystic fibrosis (CF) and bronchiectasis. ${ }^{1-4}$ This follows on from a recent series examining aspects of exacerbations of chronic obstructive pulmonary disease and asthma. These reviews involved authors from Australia, USA and the UK, and each has considered the topics from both a paediatric and adult perspective. Several themes emerge in these reviews, including: (1) the challenges of diagnostic precision of definitions of respiratory exacerbations; (2) the need to develop new and/or novel endpoints for therapeutic trials for the treatment of exacerbations; and (3) the urgent need for multicentre studies to investigate both preventive and therapeutic interventions for patients with CF and bronchiectasis.

Goss and Burns highlight recent studies which have used definitions of 
pulmonary exacerbations in patients with CF. ${ }^{1}$ While many of the multicentre studies have used formal definitions of exacerbations, all have included components which are subjective and have had only limited validation. ${ }^{5}$ Even the role of objective clinical measures in the definition of exacerbations, such as pulmonary function, has been questioned. ${ }^{1}$ Two diagnostic scores have been recent useful additions for use in therapeutic trials, but further validation is required before they can be widely applied. ${ }^{17}$ Chang and Bilton highlight the fact that very limited information is currently available on the definition of pulmonary exacerbations in patients with bronchiectasis. ${ }^{4}$

Until recently the change in forced expiratory volume in $\mathrm{l} \mathrm{s}$ has been the primary endpoint for most CF therapeutic trials. Improved median survival ${ }^{5} 89$ and reduction in the rate of decline of pulmonary function ${ }^{10}{ }^{11}$ suggest improvement in the outcome for patients with CF. Consequently, either larger study populations or longer clinical trials will be required to provide data to support the role of new treatments, if these classic trial endpoints are to continue to be used. As a result, new endpoints for trials have emerged, including changes in quality of life $^{12}$ and changes in the rates of and time to pulmonary exacerbation. ${ }^{13}{ }^{14}$ The inclusion of the latter two further highlights the need for more research on the validity of scoring systems to define respiratory exacerbations.

Evidence-based advances in the management of patients with CF have been seen in the past decade with the successful completion of numerous multicentre clinical trials. These studies have confirmed the role of mucolytics and hypertonic saline, ${ }^{6}{ }^{15}$ inhaled antibiotics (such as tobramycin), ${ }^{16}$ anti-inflammatory therapies $^{14}{ }^{17}$ and macrolides ${ }^{18} 19$ in improving clinical outcomes, including in some cases the effects on exacerbation rates $^{6} 151619$ highlighted in the review by Bell and Robinson. ${ }^{2}$ Furthermore, it is now clear that parenteral aminoglycosides (such as tobramycin) for the treatment of pulmonary exacerbations may be better administered by once daily dosing than by multiple daily doses. ${ }^{3}$ Such evidence has led to major changes in practice for patients with CF. However, each of the reviews highlights significant gaps in the knowledge of many aspects of the treatment of patients with CF and bronchiectasis. $^{1-4}$

While there are now some data supporting treatment choices for the most common bacterial pathogen in patients with CF (Pseudomonas aeruginosa), more study is required to extend the limited in vitro data to support antibiotic choices for less common and often more resistant pathogens such as Burkholderia cepacia complex, Stenotrophomonas maltophilia, Achromobacter xyloxidans and methicillinresistant Staphylococcal aureus in patients with CF. Such studies will require a collaborative and international approach to draw together sufficient patient numbers to provide study power and thus are likely to be extremely difficult to fund. Similarly, further study is required to examine treatment choices for very young children with $C F$ which, to date, have received more limited attention in multicentre therapeutic studies

There are also very few data currently available comparing the role of different treatments, both with each other and as complementary therapies. For example, we do not know whether rhDNase 1 is more effective than hypertonic saline or whether the effect of rhDNase 1 is enhanced by the administration of hypertonic saline to the same patient, or whether such combinations are counterproductive for some patients. Given that current clinical practice has often involved the addition of a new treatment modality to existing therapies, it is hoped that such comparisons could be performed in the future, particularly as many new treatments are expensive for our healthcare systems and/or are time-consuming for the patient.

Even more work remains to be performed to provide evidence to support treatment choices for patients with bronchiectasis. Most studies of preventive and treatment strategies of respiratory exacerbations in bronchiectasis have been undertaken at a single centre and have included small patient numbers where power calculations have not been reported and where the definitions of exacerbations have been limited. An important message of the study by O'Donnell et al-who reported the results of a randomised controlled trial to assess the effect of rhDNase 1 in patients with idiopathic bronchiectasis-was that, while rhDNase 1 is an effective treatment in patients with $\mathrm{CF}$, these benefits are not directly transferable to patients with bronchiectasis. ${ }^{162021}$ Studies addressing a specific treatment need to be performed in patients with bronchiectasis. The recent publication of the characteristics of a cohort of patients with bronchiectasis provides an opportunity to draw together clinicians and researchers with an interest in this understudied disease to allow the design, search for funding support and successful execution of multicentre studies. ${ }^{22-25}$ However, funding bodies will need to take a far-reaching view and to look for improved patient outcomes by evidence-based treatment strategies, as is starting to be realised for patients with CF.

Exacerbations of CF and bronchiectasis have a negative impact on patients' quality of life, require expensive treatment and are associated with poor outcomes. Finding ways to reduce the frequency of these events will improve the lives of people with chronic suppurative lung disease.

Thorax 2007;62:288-290.

doi: $10.1136 /$ thx.2006.065664

\section{Authors' affiliations}

J S Elborn, Respiratory Medicine Research Group, Queens University of Belfast and Adult CF Centre Belfast City Hospital, Belfast BT9 7AB, UK

S C Bell, Adult Cystic Fibrosis Centre and School of Medicine, University of Queensland, The Prince Charles Hospital, Brisbane 4032, Australia

Correspondence to: Professor J S Elborn, Adult CF Centre Belfast City Hospital, Belfast BT9 7AB, UK; Stuart.Elborn@bch.n-i.nhs.uk

Competing interests: None.

\section{REFERENCES}

1 Goss $\mathrm{CH}$, Burns JL. Exacerbations in cystic fibrosis 1: Epidemiology and pathogenesis. Thorax 2007:62:360-7.

2 Bell SC, Robinson PJ. Exacerbations in cystic fibrosis - 2: Prevention. Thorax 2007;62:(in press).

3 Smyth AR, Elborn JS. Exacerbations in cystic fibrosis - 3: Treatment. Thorax 2007; 62:(in press).

4 Chang $A B$, Bilton D. Exacerbations - 4: Non-CF bronchiectasis. Thorax 2007;62:(in press).

5 Cystic Fibrosis Foundation. Patient Registry Annual Data Report 2003. Bethesda, Maryland: Cystic Fibrosis Foundation, 2003.

6 Fuchs HJ, Borowitz DS, Christiansen DH, et al. Effect of aerosolized recombinant human DNase on exacerbations of respiratory symptoms and on pulmonary function in patients with cystic fibrosis. The Pulmozyme Study Group. N Engl J Med 1994;331:637-42.

7 Piedra PA, Cron SG, Jewell A, et al. Immunogenicity of a new purified fusion protein vaccine to respiratory syncytial virus: a multi-center trial in children with cystic fibrosis. Vaccine 2003;21:2448-60.

8 Dodge JA, Lewis PA. Cystic fibrosis is no longer an important cause of childhood death in the UK. Arch Dis Child 2005;90:547.

9 Elborn JS, Shale DJ, Britton JR. Cystic fibrosis: current survival and population estimates to the year 2000. Thorax 1991:46:881-5.

10 Que C, Cullinan P, Geddes D. Improving rate of decline of $\mathrm{FEV}_{1}$ in young adults with cystic fibrosis. Thorax 2006;61:155-7.

11 Xu W, Subbarao P, Corey M. Changing patterns of lung function decline in children with cystic fibrosis (abstract). J Cystic Fibros 2004;3(Suppl 1):S116.

12 Modi AC, Quittner AL. Validation of a diseasespecific measure of health-related quality of life for children with cystic fibrosis. J Pediatr Psychol 2003;28:535-45

13 Aaron SD, Vandemheen KL, Ferris W, et al. Combination antibiotic susceptibility testing to treat exacerbations of cystic fibrosis associated with multiresistant bacteria: a randomised, doubleblind, controlled clinical trial. Lancet 2005;366:463-71.

14 Balfour-Lynn IM, Lees B, Hall P, et al. Multicenter randomized controlled trial of withdrawal of 
inhaled corticosteroids in cystic fibrosis. Am J Respir Crit Care Med 2006:173:1356-62.

15 Elkins MR, Robinson M, Rose BR, et al. A controlled trial of long-term inhaled hypertonic saline in patients with cystic fibrosis. N Engl J Med 2006;354:229-40.

16 Ramsey BW, Pepe MS, Quan JM, et al. Intermittent administration of inhaled tobramycin in patients with cystic fibrosis. Cystic Fibrosis Inhaled Tobramycin Study Group. N Engl J Med 1999;340:23-30.

17 Konstan MW, Byard PJ, Hoppel CL, et al. Effect of high-dose ibuprofen in patients with cystic fibrosis. N Engl J Med 1995;332:848-54.

18 Saiman L, Marshall BC, Mayer-Hamblett N, et al Azithromycin in patients with cystic fibrosis chronically infected with Pseudomonas aeruginosa: a randomized controlled trial. JAMA 2003:290:1749-56.

19 Wolter J, Seeney S, Bell S, et al. Effect of long term treatment with azithromycin on disease parameters in cystic fibrosis: a randomised trial. Thorax 2002;57:212-6.

20 Quan JM, Tiddens HA, Sy JP, et al. A two-year randomized, placebo-controlled trial of dornase alfa in young patients with cystic fibrosis with mild lung function abnormalities. J Pediatr 2001;139:813-20.

21 Shah PL, Conway S, Scott SF, et al. A casecontrolled study with dornase alfa to evaluate impact on disease progression over a 4 -year period. Respiration 2001;68:160-4.
22 Angrill J, Agusti C, De Celis R, et al. Bronchial inflammation and colonization in patients with clinically stable bronchiectasis. Am J Respir Crit Care Med 2001;164:1628-32.

23 Chan SL, Chan-Yeung MM, Ooi GC, et al Validation of the Hong Kong Chinese version of the St. George Respiratory Questionnaire in patients with bronchiectasis. Chest 2002;122:2030-7.

24 Palwatwichai A, Chaoprasong C, Vattanathum A, et al. Clinical, laboratory findings and microbiologic characterization of bronchiectasis in Thai patients. Respirology 2002;7:63-6.

25 Pasteur MC, Helliwell SM, Houghton SJ, et al. An investigation into causative factors in patients with bronchiectasis. Am J Respir Crit Care Med 2000;162:1277-84.

\section{BMJ Clinical Evidence-Call for contributors}

BMJ Clinical Evidence is a continuously updated evidence-based journal available worldwide on the internet which publishes commissioned systematic reviews. BMJ Clinical Evidence needs to recruit new contributors. Contributors are healthcare professionals or epidemiologists with experience in evidence-based medicine, with the ability to write in a concise and structured way and relevant clinical expertise.

Areas for which we are currently seeking contributors:

- Secondary prevention of ischaemic cardiac events

- Acute myocardial infarction

- MRSA (treatment)

- Bacterial conjunctivitis

However, we are always looking for contributors, so do not let this list discourage you.

Being a contributor involves:

- Selecting from a validated, screened search (performed by in-house Information Specialists) valid studies for inclusion.

- Documenting your decisions about which studies to include on an inclusion and exclusion form, which we will publish.

- Writing the text to a highly structured template (about 1500-3000 words), using evidence from the final studies chosen, within 8-10 weeks of receiving the literature search.

- Working with BMJ Clinical Evidence editors to ensure that the final text meets quality and style standards.

- Updating the text every 12 months using any new, sound evidence that becomes available. The BMJ Clinical Evidence in-house team will conduct the searches for contributors; your task is to filter out high quality studies and incorporate them into the existing text.

- To expand the review to include a new question about once every 12 months. In return, contributors will see their work published in a highly-rewarded peer-reviewed international medical journal. They also receive a small honorarium for their efforts.

If you would like to become a contributor for BMJ Clinical Evidence or require more information about what this involves please send your contact details and a copy of your CV, clearly stating the clinical area you are interested in, to CECommissioning@bmigroup.com.

\section{Call for peer reviewers}

BMJ Clinical Evidence also needs to recruit new peer reviewers specifically with an interest in the clinical areas stated above, and also others related to general practice. Peer reviewers are healthcare professionals or epidemiologists with experience in evidence-based medicine. As a peer reviewer you would be asked for your views on the clinical relevance, validity and accessibility of specific reviews within the journal, and their usefulness to the intended audience (international generalists and healthcare professionals, possibly with limited statistical knowledge). Reviews are usually 1500-3000 words in length and we would ask you to review between 2-5 systematic reviews per year. The peer review process takes place throughout the year, and our turnaround time for each review is 10-14 days. In return peer reviewers receive free access to BMJ Clinical Evidence for 3 months for each review.

If you are interested in becoming a peer reviewer for BMJ Clinical Evidence, please complete the peer review questionnaire at www.clinicalevidence.com/ceweb/contribute/peerreviewer.jsp 